(C) М.А. Сулоева

\title{
РОЛЬ И ФУНКЦИОНИРОВАНИЕ ТРАДИЦИОННОЙ ЖЕНСКОЙ ОДЕЖДЫ АРБРЕШЕЙ ИТАЛИИ В СОВРЕМЕННОМ СОЦИОКУЛЬТУРНОМ ПРОСТРАНСТВЕ
}

\begin{abstract}
Статья посвящена традиционной женской одежде арбрешей Сищилии, в частности этнической группы, проживающей в Пьяна-дельи-Альбанези. Арбреши - это выходцы с территории Балканского полуострова, мигрировавиие в итальянские земли в XV-XVIII вв. Традиционная одежда Пьяна-дельи-Альбанези рассмотрена как иелостное этнокультурное явление, веками создаваемое и продолжающее жить в современном социокультурном пространстве. Автор прослеживает изменение женского костюма и выявляет специфику функиионирования его отдельных элементов. Проведенное исследование позволяет заключить, что для традиционной одежды арбрешей характерны относительная устойчивость основных моделей женского платья, вариативность отдельных элементов внутри комплексов, заимствование предметов одежды в результате длительного межкультурного взаимодействия с представителями доминантной культуры, а также сильное влияние европейской моды на окончательное формирование внешнего облика костюма. Арбреши считают себя хранителями и продолжателями собственных традииий, поэтому стараются создать и законсервировать определенный тип костюма, который, несмотря на включённость заимствованных элементов, воспринимается носителями и транслируется в мировое культурное сообщество как национальный. Исследовательскую базу работы составили искусствоведческие и этнографические исследования, а также собственные полевые материалы автора, собранные в ходе полевых работ, проводившихся на Сиџилии в Пьяна-дельи-Альбанези и Палермо (2016-2017 г2.), в Косово (2015 г.) и южной Албании (2014-2015 г2.).
\end{abstract}

Ключевые слова: арбреши, Пьяна-дельи-Альбанези, женская традиционная одежда, идентичность, традиции, культурная память

В традиционной культуре любого этноса одежда занимает особое место, так как в ней закодирована информация о восприятии окружающего мира. Она не только является медиативным звеном, связывающим её обладателя с другими культурами, но также участвует в процессе трансляции собственных традиций, стереотипов поведения и является важным фактором самоидентификации.

Сулоева Марина Александровна - аспирант, Музей антропологии и этнографии имени Петра Великого РАН (199034 Санкт-Петербург, Университетская наб., 3). Эл. почта: suloevamarina@ yandex.ru 
В связи с возросшим в последние десятилетия интересом к этническим меньшинствам, наблюдается возврат их представителей к собственным традициям, а также стремление к сохранению и популяризации своего культурного наследия. Представители албанской диаспоры в южной Италии и на Сицилии также пытаются адаптировать свою традиционную культуру в условиях социально-экономических и пространственно-временных трансформаций (La Barbera 2007: 111). Народный костюм перестаёт выполнять свою первостепенную функцию, его роль переосмысливается, он становится объектом культурной памяти для этноса, который переживает изменения во всех областях жизни.

Традиционную арбрешскую одежду можно считать одним из наиболее характерных элементов итало-албанской культуры наряду с религиозными ритуалами, прежде всего, церемонией венчания, проводимой в соответствии с греко-византийским обрядом, и местным диалектом албанского языка. Костюмы албанцев Италии и Сицилии - это важная часть культурного наследия, которое в XV веке привезли с собой албанские мигранты (Guagliardi 2004). Несмотря на явное стилистическое сходство, в их одежде прослеживаются региональные различия, выражающиеся в форме, цветовой палитре, материалах и аксессуарах. Это свидетельствует о том, что на формирование данного объекта культуры повлияли различные исторические контакты, происходившие в едином географическом и социокультурном пространстве.

Народный костюм является особым текстом, отражающим динамику изменений, наблюдаемых на всех уровнях жизни. Под влиянием различных инноваций меняется также специфика функционирования самого костюма и его отдельных элементов, поэтому целью данного исследования стало выявление данной специфики. Являясь составной частью материальной и духовной культуры и будучи неразрывно связанной со своим носителем, традиционная одежда арбрешей Италии выполняет функцию сохранения и трансляции культурной памяти. По этой причине использование концепта культурной памяти в отношении данного элемента культуры, представляется наиболее удачным подходом к изучению.

Основными методологическими принципами исследования послужили описательный, историко-типологический и сравнительно-исторический подходы. Рассматривая традиционный костюм как единый текст, имеющий определенную структуру и сложный комплекс различных элементов, каждый из которых выполняет соответствующую функцию, мы применили методы структурного и функционального анализа. Исторический подход позволил выявить основные закономерности генезиса и эволюции костюма. Исследовательскую базу работы составили этнографические и искусствоведческие исследования, а также собственные полевые материалы автора, собранные в ходе полевых работ, проводившихся на Сицилии в Пьяна-дельи-Альбанези и Палермо (2016-2017 гг.), в Косово (2015 г.) и южной Албании (2014-2015 гг.).

\section{К истории вопроса}

Основание Пьана-дельи-Альбанези (центра компактного проживания албанской диаспоры на Сицилии) восходит к концу XV века, когда после вторжения османской армии на Балканский полуостров многочисленные группы албанских беженцев отправились в поисках убежища на побережье южной Италии, где они осели, основав большое количество новых поселений. Регионы, в которые миграция албанцев была 
наиболее существенной, - это Калабрия, Сицилия, Молизе, Кампания, Апулия и Базиликата. К сожалению, историографические исследования, не всегда подкрепленные достаточной документацией, не позволяют доподлинно установить регионы происхождения переселенцев. Исходя из языка, религиозных обрядов, многочисленных ономастических и топонимических названий, можно утверждать, что арбреши, основавшие Пьяна-дельи-Альбанези, были родом из южных и центральных районов Албании, а также из Мореи ${ }^{1}$ - области на юге Греции (Romata 1964: 2).

Вплоть до первой половины XVIII века миграция албанского населения практически не прекращалась, насчитывается несколько периодов, в которые происходило переселение албанской диаспоры.

C середины XV века османы подчинили себе почти весь Балканский полуостров, за исключением небольшой прибрежной полосы вдоль Адриатического моря, которая включала в себя современную Албанию. В этом регионе албанцы под руководством Скандербега² оказывали сопротивление армиям султана в течение двадцати пяти лет (Арш 1992). Благодаря своим военным успехам, Скандербег получил помощь и поддержку Альфонсо V Арагонского (1396-1458 гг.), короля Неаполя, который планировал расширить свою империю от Гибралтара до Босфора. Скандербег был связан с неаполитанским королем договором, который включал в себя признание протектората Неаполя над Албанией и одновременно обязывал Албанию предоставить в случае необходимости военную помощь Неаполю (Zangari 1940: 45).

Первые албанские колонии возникли в 1448 году, когда три тысячи албанских страдиотов $^{3}$ во главе с Деметрио Рересом и его сыновьями Джорджио и Базилио были отправлены Скандербегом в Калабрию, чтобы оказать помощь Альфонсо V в подавлении вспыхнувшего восстания баронов (Romata 1964). В награду за военные услуги король Неаполя назначил Ререса губернатором Калабрии, а также передал ему земли, на которых были основаны первые арбрешские деревни (Zangari 1940: 52). Король считал, что присутствие албанцев в этом регионе также будет препятствовать любым дальнейшим попыткам восстания. Позднее, с нарастающим давлением османских завоевателей, Албанию стали покидать новые группы мигрантов, воспользовавшись тем, что в Калабрии уже были основаны первые колонии (Mastroberti 2008: 149).

Другая волна переселения восходит к 1461-1468 годам. В этот период в Неаполитанском королевстве вспыхнула гражданская война, и новый король Фердинанд I (1423-1494 гг.) вновь обратился к Скандербегу за помощью. Воспользовавшись установившимся перемирием с турками, Скандербег отправился со своим небольшим войском в Италию (Арш 1992). По окончании войны многие из албанских солдат остались в Молизе, где они основали новые поселения (Mastroberti 2008: 150).

Самая крупная и продолжительная миграция албанского населения датируется 1468-1506 годами, когда после смерти Скандербега все большее число албанских городов и крепостей оказывалось под османским управлением (Арш 1992: 76-78). Население Албании подвергалось преследованиям и массовым убийствам, поэтому многие албанцы последовали примеру тех, кто ранее поселился в южной Италии. Прибытие албанских беженцев могло в значительной степени укрепить экономику и демогра-

\footnotetext{
${ }^{1}$ Морея - средневековое название полуострова Пелопоннес.

${ }^{2}$ Скандербег, или Георг Кастриоти (1405-1468 гг.) - правитель княжества Кастриоти, вождь антиосманского албанского восстания, национальный герой Албании, воспеваемый в народных песнях (Ари 1992: 56-62).

${ }^{3}$ Страдиоты - наёмники балканского происхождения.
} 
фию малонаселенных районов, поэтому многие из албанцев при одобрении католической церкви получили землю и права от местных феодалов (Emmanuele 1988: 90).

Часть беженцев обосновалась в Неаполитанском королевстве, в горных районах вокруг Беневенто, а также в провинции Потенца в Бариле, Джинестре, Маскито и Мелфи, где они заселили заброшенные деревни, разрушенные землетрясением (Romata 1964: 16). Остальные отправились в Калабрию, где в районе Козенца основали многочисленные деревни (Zangari 1940: 85). Семьи старой албанской знати поселились в Трани и Отранто. Тем временем на Сицилии появились новые поселения: в провинции Катания - Бьянкавилла, в Палермо - Палаццо-Адриано, а в 1488 году Бронте и Пьяна-деи-Гречи ${ }^{1}$ (Romata 1964: 17).

Следующая волна миграции произошла в 1534 году и была массовым перемещением греческих и албанских беженцев из Мореи, в частности из города Корона, чьё население было в основном греческим, но существовало албанское меньшинство православной веры, которых местные жители называли арванитами. После подписания мирного договора между Карлом V (1500-1558 гг.) и Сулейманом I (1494-1566 гг.), город Корона был оставлен османам, однако по условиям договора граждане, которые захотели бы покинуть город, могли сесть на один из кораблей, посланных Карлом V, и найти убежище в Италии. Неаполитанское правительство наняло несколько торговых судов для переправы греческих и албанских (арванитских) семей Короны, которые предпочли найти новый дом в провинциях южной Италии. Около двух тысяч человек были перевезены к берегам Неаполитанского королевства (Romata 1964: 20).

Так, например, близ города Потенца (провинция Базиликата) были основаны деревни Бариле, Бриндизи-Монтанья, Джинестра, Мельфи, Сан-Костантино-Альбанезе, Сан-Пауло-Альбанезе и Сан-Джорджо-Лукано, а в Калабрии - Кастрореджио и Фарнета (Romata 1964: 22). Другая группа мигрантов обосновалась в городе Гречи в провинции Авеллино. Некоторые албанцы по-прежнему отправлялись заселять различные полуразрушенные фермерские дома в районе Таранто, другие же поселились на Сицилии, переехав жить в поселения, основанные ранее (Mastroberti 2008: 152).

C тех пор было еще несколько волн миграции с территории Албании, хотя и не таких значительных. Мигрировавшие в итальянские земли албанцы принадлежали в конфессиональном плане к католицизму или православию. После того, как поселенцы признали главенство папы, «Православная Церковь албанцев стала называться Римской католической церковью восточного обряда с вытекающим отсюда поклонением византийским святым, с греческими иконами, с молитвами и языками богослужения -греческим и арбрешским» (Новик 2011: 133).

Влияние соседей-итальянцев в значительной мере сказалось на всех уровнях культурно-социальной жизни: архитектура, способы ведения хозяйства, социальные институты, одежда, кухня и ритуальные практики. Многие из основанных мигрантами поселений со временем утратили свои этнокультурные особенности. Полностью ассимилированные албанские поселения в основном находятся в Апулии, что может быть объяснено равнинным расположением и близостью к крупным городам, таким как Таранто и Лечче (Romata 1964: 26).

Однако некоторые колонии, хотя и подверглись в значительной степени итальянизации, все же сохраняют хорошо узнаваемые черты, присущие албанской культуре. Деревни, население которых в наибольшей степени сохранило этническую и

${ }^{1}$ Пьяна-деи-Гречи - первоначальный вариант названия Пьяна-дельи-Альбанези. 
лингвистическую самобытность, находятся в Калабрии и на северо-западе Сицилии, в отдаленных горных районах, которые долгое время в прошлом были недоступны для транспорта (Romata 1964: 27). В этих землях поселенцы продолжают вести привычный образ жизни, говорить на языке отцов, поддерживать византийский религиозный обряд, справлять народные праздники и передавать из поколения в поколение фольклор и ритуальные практики, а в сфере материальной культуры сохранять традиционный костюм, украшения и прочие предметы быта в аутентичном виде, характерном для запада Балканского полуострова.

Таким образом, в Южной Италии и на Сицилии появились районы, компактно заселенные албанцами, сохраняющими свой язык, обычаи, вероисповедание, а также прежний, бытовавший до начала переселения этноним арбреш (apбp. arbresh).

\section{Традиционная женская одежда Пьяна-дельи-Альбанези}

Говоря о традиционной одежде арбрешей Сицилии, мы можем выделить женские костюмы, так как мужская одежда со временем утратила свои специфические характеристики и довольно быстро вышла из употребления, в отличие от одежды калабрийцев ${ }^{1}$, которая в значительно меньшей степени подверглась инновациям (La Barbera 2007). Кроме того, по словам информантов, в Калабрии с начала 60-х годов $\mathrm{XX}$ века в ходе реконструкции было создано около пятнадцати мужских костюмов в балканском стиле, предназначавшихся для самых важных мероприятий (ПМА 3).

Однако привезенный на Сицилию албанскими мигрантами оригинальный мужской костюм, испытав на себе влияние итальянской моды очень быстро утратил свои характерные особенности и региональные отличия, а затем был полностью вытеснен местной одеждой. По мнению информанта Габриэле Паррино (арбреш, 1990 г.р., Пьяна-дельи-Альбанези), это связано с тем, что на новых землях мужчинам приходилось думать о заработке, обустраивать быт и налаживать социальные связи с соседями-сицилийцами, в процессе чего албанцами были заимствованы не только местные обычаи, но и одежда. Приведем отрывок из его нарратива:

«Будучи албанцем, мигрировавщим в итальянские земли, ты вынужден принимать законы и обычаи того места, где теперь строишь новую жизнь. Кроме того, мужчины по своей природе больше стремятся к удобству и практичности, поэтому традиционная мужская одежда была так быстро утрачена. Я думаю, что женский костюм сохранился потому, что в нашем сознании женщина была драгоценным камнем, ядром своей семьи, поэтому заслуживала одеваться в самье лучшие и дорогие наряды. Албанки действительно пользовались большим уважением со стороны своих мужчин, несмотря на патриархальный уклад жизни» (ПМА 4: Паррино).

Сегодня в Пьяна-дельи-Альбанези для тех мероприятий, которые предполагают ношение традиционного костюма, мужчины используют традиционную албанскую или калабрийскую одежду, а именно: короткую бархатную куртку, белую рубашку, безрукавку, узкие длинные штаны, расшитые черной тесьмой, либо юбку фустанеллу (алб.

${ }^{1} \mathrm{~B}$ XIX веке, во времена французской оккупации, появились первые отличия типичной мужской калабрийской одежды: классический конический головной убор из черной ткани с лентами разных цветов, короткая бархатная куртка, обтягивающие до колена бархатные брюки, заправленные в гетры, кожаные туфли со шнурками, завязанными под коленом (Zangari 1940: 75). 


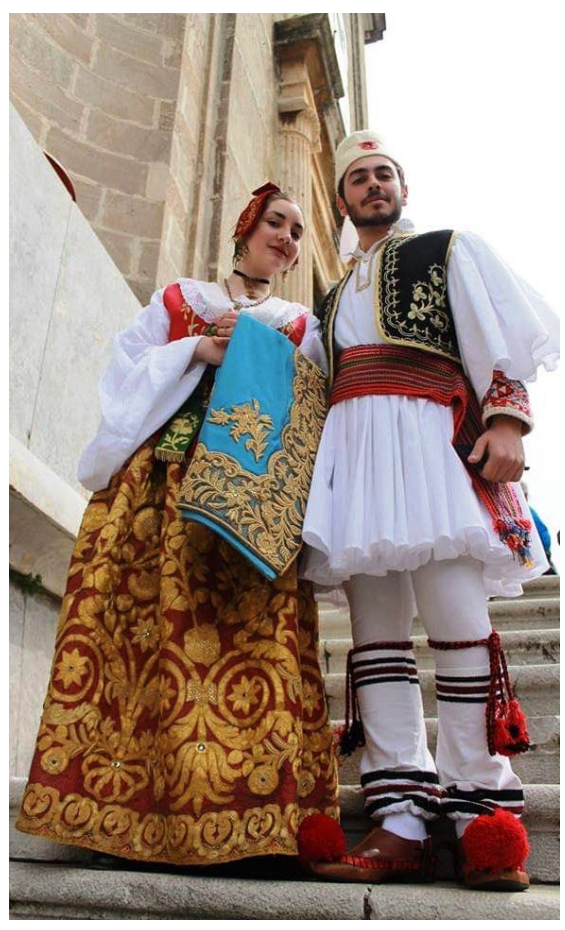

Рис. 1. Слева представлен женский арбрешский традиционный костюм, справамужской албанский. (Пьяна-дельиАльбанези, 2015 г., фото из архива С. Скиро) fustanella), шерстяные носки и характерную обувь с помпонами - опинги (алб. opinga) (ПМА 2). Мужской костюм или его отдельные элементы покупаются в Албании, Греции и Косово (Рис. 1).

Женская одежда, о которой пойдет речь в данной статье, является не только культурным наследием, признаком социального статуса, но и одним из ключевых маркеров идентичности современных арбрешей, и тем самым представляет особый интерес для исследования. В настоящее время костюмы продолжают привлекать ученых, экспертов моды, репортеров прессы и телевидения, туристов.

Традиционный костюм арбрешей стал частью этнической истории не только для представителей албанской диаспоры, но также для других языковых меньшинств Италии. Сегодня еще можно найти уникальные подлинные наряды XVII-XIX веков, которые удалось сберечь и передать последующим поколениям как семейную реликвию. В арбрешских сёлах еще есть пожилые албанские женщины, которые с гордостью носят свою старую одежду. С годами такие костюмы становятся все большей редкостью, а их ценность растет.

Традиционная одежда арбрешей Сицилии претерпевала значительные изменения на протяжении пяти веков, и на формирование ее отдельных элементов, богатство вышивки, используемые ткани и способ ношения повлияла сицилийская одежда XVII века, а также тенденции европейской моды XIX века. Окончательный же вид костюм приобрел в период между XIX - началом XX века, и новые формы дошли до наших дней практически без изменений.

Историко-научная реконструкция традиционной женской одежды в албанских общинах Италии представляет трудную задачу для исследователя. Чтобы проследить все этапы эволюции костюма, недостаточно использовать только графические данные, представленные иконографией, гравюрами и живописью. Поскольку богато убранные одежды и драгоценности часто передавались по наследству, решающий вклад принадлежит систематическому исследованию таких архивных источников XVI и последующих веков, как завещания и содержащиеся в них письменные описания (La Barbera 2007: 112).

Одним из ключевых этапов восстановления первоначального облика костюма, становится изучение иконографических источников, которые, хотя и не могут дать исчерпывающего представления, но, безусловно, вносят эффективный вклад в лучшее понимание этого наследия народного искусства.

С появлением фотографии становится легче реконструировать историческую память, особенно в случае с женской традиционной одеждой, поскольку женщи- 
ны позволяют себя фотографировать в самые важные события своей жизни. Кроме того, использование традиционной одежды часто связано с важными религиозными и историческими праздниками, а также семейными мероприятиями, когда представители того или иного этноса начинают позиционировать свои исторические корни и значительное лингвистическое, религиозное и традиционное наследие, которые на протяжении веков они сохраняли. Среди событий, во время которых фотографам удалось запечатлеть арбрешскую одежду, были костюмированные представления, ставившиеся в Лунгро в 60-х годах по эпическим произведениям, воспевающим жизнь и подвиги национального героя Скандербега, а также ежегодные пасхальные шествия в Пьяна-дельи-Альбанези.

Многие черты традиционного костюма Пьяна-дельи-Альбанези сближают его с одеждой, которую носили в XVII в. в Палаццо-Адриано ${ }^{1}$ (город, также основанный албанцами), что, безусловно, предполагает общее происхождение, однако не совсем верно утверждать, что прототипом полностью послужил албанский костюм. С конца первого тысячелетия албанские земли испытывали влияние византийской культуры, о чем свидетельствуют яркие цвета, широкая драпировка, длинные широкие рукава, богатые ткани и использование золотной вышивки и драгоценных камней в убранстве одежды. C XV века при пошиве албанской одежды использовались ткани, технологии и крой, которые были приняты на западе, прежде всего в Венеции и Анконе. До вторжения Османской империи на Балканы албанское платье имело прямой или слегка расклешенный силуэт, поэтому мы можем сделать выводы, что не оно послужило прототипом традиционного арбрешского костюма (Gjergji 1988: 285).

Итальянская мода испытала на себе влияние как Византии, так и центров исламского мира. Венецианская республика на протяжении длительного времени имела тесные торговые связи с Византией, продолжившиеся после османского завоевания, но уже с турецким Константинополем. В Венецию поступали дорогие восточные ткани, меха и украшения, а также под влиянием ориентальной моды шло собственное производство, все это затем отправлялось в другие провинции Италии (Новик 2011: 142). Юг страны, в частности Калабрия, также был связан с Византией и Османской империей, что напрямую отразилось на манере одеваться. Так, в XVII в. в моду вошли широкие юбки с многочисленными складками, собранными на талии. В XVIII в. на юбке появляются полосы кружева, плетенного на коклюшках. Именно этот вид юбки и послужил прототипом арбрешского свадебного платья, который до конца XVIII в. использовался как обычный праздничный наряд (La Barbera 2007:115-117).

О сильном влиянии не только сицилийской, но и испанской моды свидетельствует крой некоторых элементов костюма, таких как нижняя рубашка и жакет, надевавшийся сверху. Одной из самых специфических и, безусловно, оригинальных деталей является кеза (арбр. keza) - женский головной убор; когда-то он использовался всеми

\footnotetext{
${ }^{1}$ По сведениям, полученным от информантов, традиционная женская одежда Палаццо-Адриано сохранилась лишь в нескольких экземплярах, представленных в местных музеях, и более не является культурной реальностью для его жителей. В начале 2000-х годов монахиня византийского католического обряда Исидора Петта (1925-2016 гг.), арбрешка из Пьяна-дельи-Альбанези, попыталась реконструировать женский костюм, некогда бытовавший в Палаццо-Адриано. Прототипом послужила одежда, обнаруженная во время раскопок местных захоронений, а также современные костюмы Пьяна-дельи-Альбанези. В 2004 году Илария Паррино, представлявшая Палаццо-Адриано на ежегодном конкурсе Miss Arbreshe, победила в наряде, сшитом Исидорой Петтой (ПМА 4: Паррино).
} 
женщинами и был представлен в праздничном и будничном вариантах. Сегодня он нагружен новой символикой и надевается только в день свадьбы. Драгоценности также являются неотъемлемой частью костюма. Серебряный пояс брез (apбр. brez) - это результат эволюции восточного серебряного пояса за счет постепенного увеличения и изменения внешнего вида его центральной бляхи (Schirò 2011: 239-243).

Практически непрерывное производство традиционной одежды в Пьяна-дельи-Альбанези связано с большим мастерством местных женщин. На протяжении веков албанки, владеющие как простой иглой, так и ткацким станком, превращали шёлковые, бархатные и атласные ткани, импортированные из Неаполя, в изысканную одежду, убранную кружевом, плетенном на коклюшках, или золотной вышивкой (Manali 2005). Сначала изготовление костюма было исключительно домашним трудом, причем женщин обучали этому умению с раннего детства, так что уже в подростковом возрасте девочка обладала достаточными техническими навыками, с помощью которых могла сама сшить наряд для важного события. Кроме того, в XVIII в. сестры коллегии Св. Марии, специалисты по вышивке золотом, основали школу, где обучали этому искусству незамужних девушек (Schirò 2011: 240).

Классификация традиционной одежды может быть произведена по её сезонному использованию. Зимнее платье изготавливали из шерстяных и полушерстяных тканей, а также бархата и тафты, при этом предпочтение отдавали в основном черному или серому цвету. Летние платья отличались большим разнообразием тканей из шелка и хлопка (тафта, атлас, креп-жоржет) и более яркими цветовыми характеристиками.

Праздничное платье традиционно предназначалось для самых значимых событий в жизни, таких как крещения и свадьбы, а также для крупных религиозных праздников: день Св. Георгия, Богородицы Одигитрии, Св. Димитрия. Оно представлено в двух вариантах, которые различаются по типу юбки.

Первая называется нщилёна (арбр. ncilona), сшитая из красного шёлка. По всему полю юбки идет орнамент, основным мотивом которого являются цветы. Её предшественницей была так называемая пампинья (арбр. pampinja) - парчовая юбка, с узором из разноцветных хлопковых нитей, со временем вместо парчи стали широко использовать дамаст ${ }^{1}$. В последние десятилетия умелыми руками вышивальщиц Пьяна-дельи-Альбанези были созданы многочисленные нилиёны, украшенные богатой и обильной вышивкой, чей первоначальный орнамент был изменен на акантовый ${ }^{2}$ мелкими золотыми или серебряными цветами (La Barbera 2007: 123).

Второй вариант юбки - джелона (арбр. хhellona) - обрамлен рядами кружева, сплетенного из золотых или серебряных нитей на коклюшках. Количество таких рядов варьируется от одного до трех в зависимости от функции использования. Джелона с одним рядом кружева предназначалась для ежедневных религиозных служб, с двумя - для воскресной мессы, с тремя рядами - для более важных мероприятий, таких как праздник Святого Георгия, покровителя Пьяна-дельи-Альбанези (Schirò 2011: 232-233).

${ }^{1}$ Дамаст (дамаск) - шёлковая, шерстяная или хлопчатобумажная ткань полотняного или крепового переплетения, иногда в комбинации с атласом. Хлопчатобумажный дамаст используется для изготовления женского белья, в декоративных целях, шёлковый - в основном в декоративных целях. B XVIII веке эта ткань часто имитирует кружево. Названа по городу Дамаск в Сирии, где её изготавливали (Андреева 1997: 150).

2 Акант - декоративная форма, восходящая к рисунку листьев травянистого растения акант (Плужников 1995: 12). 
Другими частями, составляющими праздничный наряд, являются: белая льняная рубаха линья (арбр. linja) с длинными и широкими рукавами, украшенная кружевом, плетенным на коклюшках, кружевной элемент петини (apбp. petini) ${ }^{1}$, покрывающий верхнюю часть груди; лиф крахет (арбр. krahët) без рукавов из красного шёлка, расшитый золотом, или бархатный жакет джипуни (арбр. хhipuni) с воротником и манжетами из темного бархата с вышивкой; синяя шелковая накидка мандилина (арбр. mandilina) с золотой окантовкой; по всему костюму завязаны шелковые накладки в виде лент шкокат (арбр. shkokat). Часто в дополнение к джелоне женщины надевают фартук из черного кружева - вантерья (apбp. vanterja), но он может сочетаться также и с нцилёной. Главным и завершающим элементом обоих вариантов является серебряный пояс брез (аpбp. brez), состоящий из нескольких массивных пластин. Центральная пластина пояса украшена изображением святого покровителя (Sciascia 1966: 140).

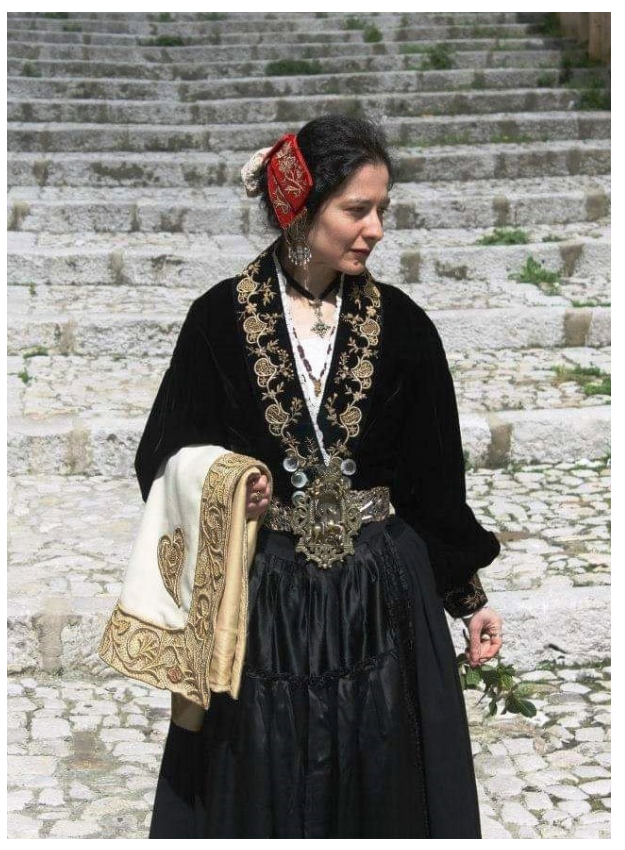

Рис. 2. Зимний вариант женского традииионного костюма (Пьянадельи-Альбанези, 2015 г., фото из архива С. Скиро).

Существовала также зимняя версия выходного платья, которое носили только замужние женщины, его основные элементы: широкая черная юбка из тафты, бархатный жакет джипуни, белая накидка с вышивкой «медовые соты» и накладка из четырех лент-лепестков на голову - шкокат (Рис. 2).

Шкокат имеют одинаковые цветочные мотивы в вышивке, исключение составляют лишь те, что крепятся к голове поверх прически и на спину, их орнамент может варьироваться. Различают разные виды шкокат по количеству так называемых лепестков, которые формируют бант. В праздничном платье с юбкой нцилёна используется четырёхлепестковый бант, который украшает переднюю часть костюма и крепится на животе над серебряным поясом или прямо под ним. До 20-х годов $\mathrm{XX}$ века такое украшение имело только два лепестка. В выходном варианте костюма с юбкой джелона используется ленточный бант с пятью лепестками из расшитого золотной нитью шелка или бархата зелёного цвета. В обоих типах праздничного платья используется двухлепестковый бант для спины и четырёхлепестковый - для поддержания причёски (Schirò 2011). В свадебном костюме число шкокат равняется двенадцати, что соответствует числу апостолов.

С конца 40-х годов XX в. практика плетения кружева из золотых нитей на коклюшках, служившего основным украшением джелоны, становится все большей редкостью и совсем исчезает, поэтому в 80-х и 90-х годах мастера занимаются изготовлением и реставрацией только юбки нциилёны. Невозможность плетения аутентичного кружева была связана также с ухудшившимся качеством золотных нитей, постоянно ломавшихся во время изготовления (La Barbera 2007: 113).

\footnotetext{
${ }^{1}$ Петини - кусок кружева, обрамленный тканью, который закладывают под лиф на груди (ПМА 3).
} 
Традиционный свадебный костюм для арбрешей является одним из самых очевидных символов культурной самобытности. В отличие от выходного костюма, претерпевшего значительные изменения и утратившего своё первоначальное предназначение, свадебное платье арбрешей Сицилии по-прежнему используется и является более предпочитаемым, чем так называемое европейское белое (или любое другое) платье (Сулоева 2019: 458-459).

Свадебный костюм, используемый в настоящее время, во многом соответствует праздничному варианту, что свидетельствует о том, что ранее его надевали и вне брачного контекста, в этом случае он сопровождался накидкой. Как и в праздничном костюме, здесь используется юбка нщилёна из красного шелка, расшитого цветочными узорами, а именно орнаментом вити (арбр. viti), который представляет собой переплетения цветов, разбросанные по всей поверхности ткани. Есть также и нижняя юбка, подол которой украшен мелкой вышивкой. Одним из ключевых элементов является линья - шелковая или льняная блуза, имеющая кружевную оторочку рукавов и нижней части подола, причем рукава расширяются от локтя вниз в соответствии с модой XV века. В то время рукав являлся самой драгоценной частью платья (Siragusa 2009). На блузу надевают крахет - шелковый лиф, вышивка которого сочетается с мотивами, использующимися в украшении юбки.

Большую выразительность костюму придают ленты шкокат. В отличие от выходного и праздничного платья, где шкокат украшают только голову, спину и живот

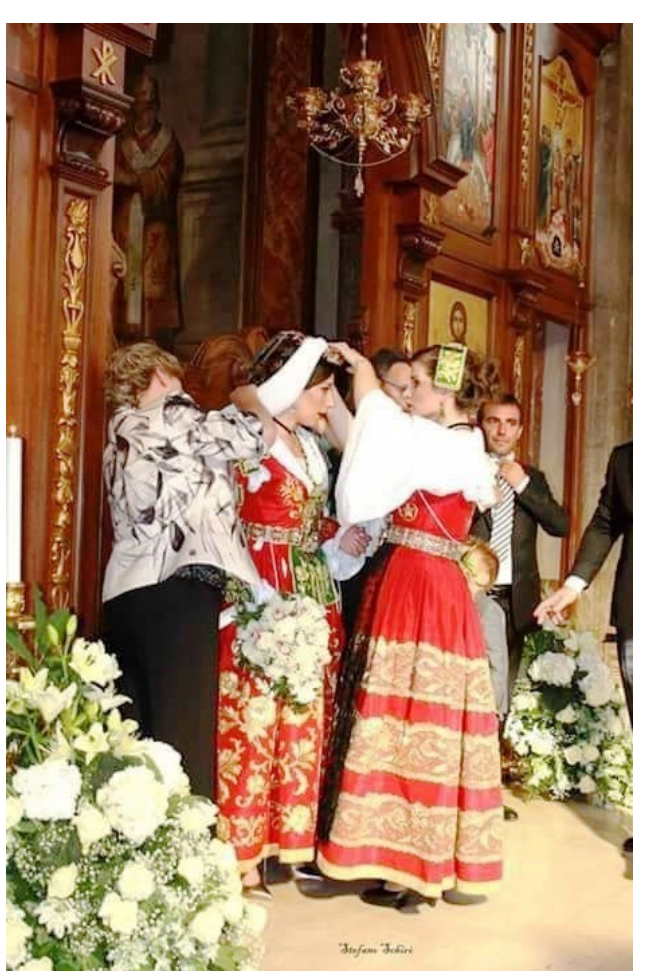

Рис. 3. Слева представлен костюм невесты с юбкой нцилёна, справапраздничный вариант с юбкой джелона. (Пьяна-дельи-Альбанези, 2015 г., фото из архива С. Скиро). женщины, в свадебном платье помимо основных переднего и заднего бантов, используются дополнительные четырёхлепестковые, которые крепятся по всей длине рукавов. Другой четырехлепестковый бант, также завязанный из лент, расшитых канителью, располагается спереди и покрывает живот невесты над юбкой (Schirò 2011: 235-237). Такой бант является не только аксессуаром свадебного костюма, но и символизирует будущее материнство (Рис. 3).

Еще одной важной деталью свадебного костюма является кеза - особый головной убор, полый внутри, изготовленный из бархата малинового или зеленого цвета и расшитый золотом или серебром (Bellusci, D'Agostino 2006, I: 170). Кеза используется для закрепления и поддержания вуали ске$n u$ (арбр. sqері) и становится символом нового социального статуса невесты (Schirò 2009: 94). Шелковая вуаль скепи крепится к головному убору и с двух сторон к поясу невесты и используется только как элемент свадебного костюма.

Большую роль во всех вариантах традиционной женской одежды играют украше- 
ния из драгоценных металлов, поскольку они дополняют и объединяют декоративные элементы во всем их многообразии. Главным среди украшений костюма является серебряный пояс брез, который состоит из пластин с изображением религиозных сюжетов, соединенных в центре при помощи особой шпильки, непременно выточенной вручную (Schirò 2014). Пояс используется в некоторых важных обрядах предсвадебного цикла, например, в ритуальном обмене подарками во время помолвки, происходящей в доме невесты. По сведениям, полученным от информантов, жених дарит своей невесте брез, который она должна будет надеть на церемонию венчания. Пояс изготавливается на заказ у местного мастера и стоит дорого, и в случае невозможности приобрести данное украшение, мать жениха одалживает невестке свой (ПМА 4).

В албанском языке слово brez означает не только непосредственно «пояс», но также «поколение, линии преемственности, потомство», что подтверждает тот факт, что пояс является также символом материнства (Thomai et al. 2002: 25). Обладательница пояса надеется получить заступничество и / или защиту избранного святого покровителя. Именно поэтому ключевыми фигурами, изображенными на центральной бляшке, становятся, св. Георгий, св. Дмитрий, Мадонна Одигитрия и др. (Siragusa 2009: 65). Следовательно, брез выступает не только как декоративный элемент женского традиционного костюма, но также выполняет религиозную и апотропеическую функцию. До 30-х годов прошлого века незамужние девушки не могли носить брез, поэтому в соответствии со своим статусом они получили особую терминологическую маркированность - sbrezuame («без пояса»). Однако сегодня его носят и до свадьбы, например в Страстную неделю и пасхальное воскресенье. По окончании литургии сотни девушек выходят на улицы деревни, чтобы принять участие в праздничном шествии (ПМА 3, 4).

Нами зафиксировано, что все три вида костюма - выходной, праздничный и свадебный, неизменно дополнены украшениями из золота или серебра. Среди основных: обручальное кольцо доманти (арбр. domanti), серьги с пятью подвесками пиндайет (арбр. pindajet), которые обычно принимают форму распятия, чётки русари (арбр. rrusari), представляющие собой гранатовое ожерелье с медальоном, в который вставлено миниатюрное изображение святого покровителя, а также крест на бархатной ленте, инкрустированный драгоценными и полудрагоценными камнями (Schirò 2009: 100). Все эти изделия представляют огромную ценность и передаются по наследству от матери к дочери, однако не являются подлинно албанскими по происхо-

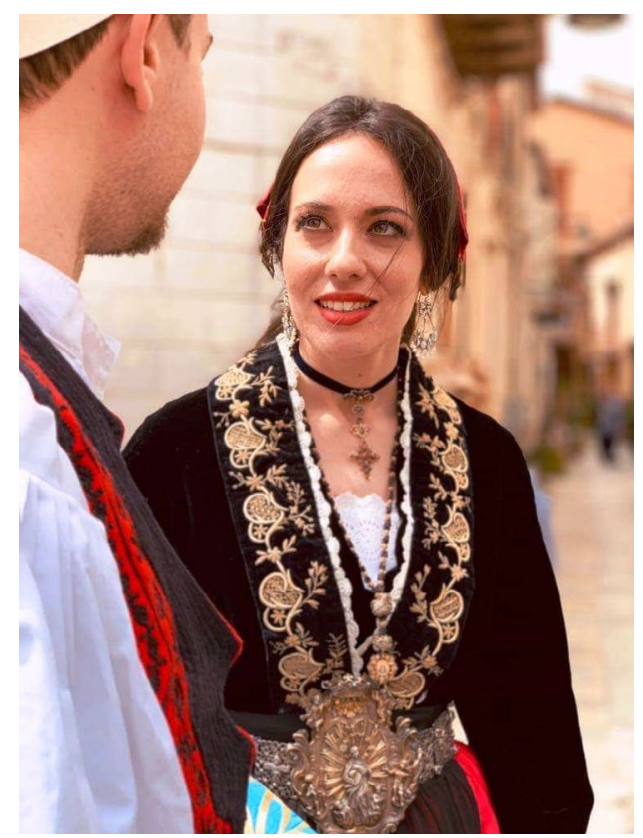

Рис. 4. Украшения, дополняюшие костюм. (Пьяна-дельи-Альбанези, 2019 г., фото из архива С. Скиро). ждению. Подобные украшения из золота, иногда эмалированные, с инкрустациями из рубинов, изумрудов, бриллиантов и других камней старой огранки можно встретить и среди сицилийских ювелирных изделий XVII-XVIII веков (Di Natale 2000: 194) (Рис. 4). 
Комплекс траурной одежды включал юбку фодийя (арбр. fodhija) из черной тафты с бархатным подолом того же цвета, черный бархатный или шелковый жакет джипуни, кружевной элемент петини, покрывающий верхнюю часть груди. Отличительной чертой данного наряда являлась широкая накидка из черной тафты в форме полумесяца, которая крепилась к голове и ниспадала широкими складками (La Barbera 2007: 120). Замужние женщины носили траурное платье без драгоценностей. Однако на пятничную литургию, а также во время Страстной недели можно было дополнить наряд серебряным поясом. В те же праздничные дни молодые незамужние женщины надевали юбку пампинья из дамаста с черной мантией (La Barbera 2007: 121).

Стоит также упомянуть полностью вышедший к настоящему времени из бытования вариант повседневного костюма, который состоял из широкой юбки в пол, сшитой из черной тафты, бархата, атласа или хлопчатобумажной ткани различных цветов (черного, фиолетового, синего, зеленого и др.), блузы с широкими рукавами, плотно прилегающими к запястьям, а также плаща - белого в летний период, светло-синего в зимний, окантованного белой шелковой лентой. Разнообразие используемых в наряде цветов также указывало на социальный статус женщины (Schirò 2009: 97).

\section{Трансформации бытования женской традиционной одежды Пьяна-дельи-Альбанези в XX - начале XXI вв.}

Ношение народной одежды не всегда было однородным и испытало несколько стадий упадка и подъёма. В XX веке традиционный костюм постепенно уступил место современной моде. Этот процесс не был единовременным, потребовался не один десяток лет, чтобы стремление к практичности и достижению экономического благополучия вытеснило традицию. В конце XIX века видеть женщин в традиционных платьях было частью повседневной жизни, однако новая европейская мода ХХ ввела практичную и легкую одежду, освободив женщин от длинных и объемных юбок. Албанки Сицилии не сразу приспособились к инновациям. Молодые женщины первыми отказались от повседневного варианта традиционного платья.

Затем в 30-х и 40-х годах комплекс с юбкой джелона, предназначенный для посещения церкви, стал менее предпочитаемым по сравнению с новой одеждой, которую присылали из Америки родственники, эмигрировавшие туда в предыдущие десятилетия. Вместо выходного платья использовался праздничный костюм с юбкой нцилёна, при этом соответствие наряда степени важности события перестало строго соблюдаться (Schirò 2009: 93).

В послевоенный период и 50-е годы, отмеченные в Италии экономическими трудностями и бедностью населения, было не так легко найти дорогие материалы для изготовления парадного костюма. В те годы женская традиционная одежда Лунгро и Пьяна-дельи-Альбанези переживала упадок: костюмы больше не шили из дорогостоящих материалов, не использовали в отделке золотые и серебряные нити, популярными становились наряды более низкого качества, которые, тем не менее, по-прежнему могли позволить только состоятельные люди (La Barbera 2007: 129).

Традиционная одежда еще не окончательно исчезла, а продолжала быть популярной на свадьбах, религиозных праздниках и других значимых событиях общественной жизни. С 1960-х годов её использование начало ослабевать наряду со многими другими традициями, такими как похищение невесты будущим мужем во время це- 
ремонии помолвки. Традиционный костюм стал восприниматься новым поколением как пережиток прошлого. На один из ежегодных карнавалов (apбp. Kalivari), которые до сих пор проходят в Пьяна-дельи-Албанези, несколько представительниц арбрешской диаспоры выбрали в качестве маскарадного традиционный костюм, который было принято надевать только по особым поводам. Этот случай вызвал крайне негативную реакцию со стороны женщин старшего поколения, поскольку был расценен как проявление неуважения к собственным традициям (ПМА 4: Паррино).

Накануне экономического бума (середина 50-х - середина 70-х гг.) многие албанские женщины стали одеваться all 'italiana или da signora («как итальянка»), что означало окончательный отказ от традиционного костюма в пользу практичности. Исключение составляло только свадебное платье, которое не утратило актуальности из-за своего особого предназначения и символической нагрузки (Guagliardi 2004). Однако сегодня мы являемся свидетелями повторного открытия культурной и исторической ценности этих характерных элементов народной культуры арбрешей. За последние тридцать лет - после повторного открытия языковых меньшинств на Сицилии и возросшего к ним интереса - возникли немногочисленные частные мастерские, занимающиеся изготовлением костюмов на заказ.

В условиях унификации и стандартизации современной культуры через средства массовой информации для представителей языковых меньшинств Италии становятся как никогда актуальными поддержание и развитие традиционных материальных памятников, и их трансляция в мировое культурное пространство. В качестве примера можно привести ежегодное празднование Пасхи, которое является не только одним из самых значимых религиозных событий, но также своеобразной опорой традиционной культуры арбрешей, символом преемственности поколений, а также живучести в условиях длительных межэтнических и межязыковых контактов.

В Страстную неделю в Пьяна-дельи-Альбанези устраивают народные шествия, в которых участвуют все жители деревни. Ношение традиционного костюма становится своеобразным способом выразить личные и национальные значения, а также приобщиться к глобальным тенденциям. Это культурный и художественно-творческий процесс, в котором албанский этнос является одновременно создателем, хранителем и продолжателем такого этнокультурного явления, как костюм.

Традиционная одежда продолжает жить, хотя и в трансформированном виде, адаптированном под новые условия современной жизни. В ходе полевой работы, проведенной в Пьяна-дельи-Альбанези в марте 2017 года, нами было отмечено, что именно в пасхальное воскресенье и дни, предшествующие ему, наблюдаются отклонения в традиционном способе ношения женского костюма. Частым явлением становится неверное сочетание элементов, относящихся к разным комплексам одежды. Например, в качестве верха к юбке пампинья вместо лифа без рукавов надевают болеро, сшитое из той же ткани, что и юбка. Некоторые из представительниц арбрешской диаспоры путают количество лент шкокат, присущих разным видам юбки, или добавляет их к рукавам или вороту куртки джипуни. Иногда наблюдается перегруженность образа современными аксессуарами, такими как часы, солнцезащитные очки, различная бижутерия, в то время как основные детали костюма (например, накидка и головной убор) отсутствуют (ПМА 3). Зачастую бросаются в глаза неуместная обувь или не соответствующие друг другу макияж и прическа (Рис. 5). 


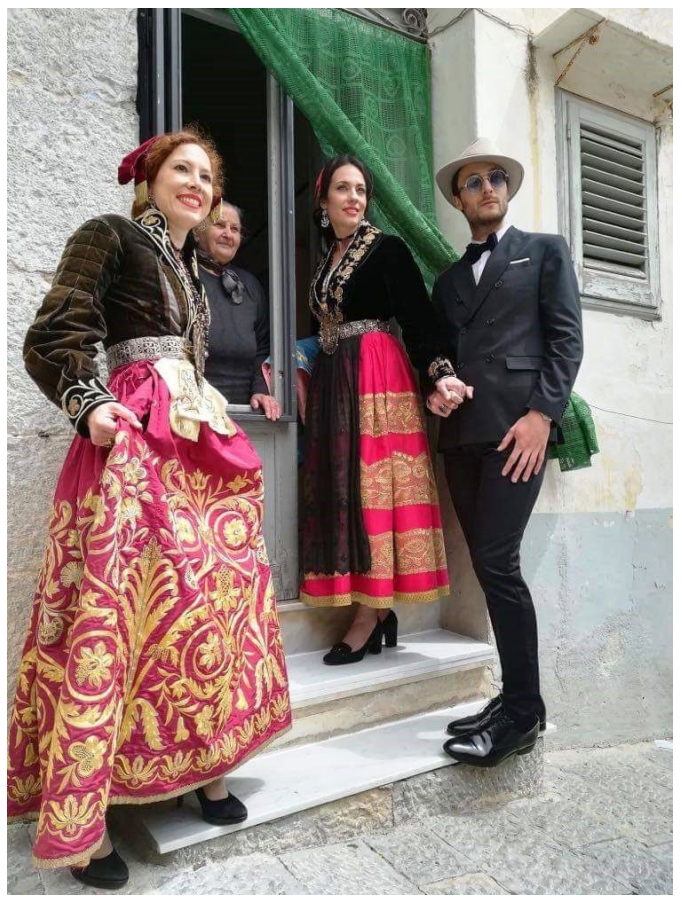

Рис. 5. Современная интерпретация традиционной женской одежды. (Пьяна-дельи-Альбанези, 2019 г., фото из архива С. Скиро)

Совсем иначе обстоит дело со свадебным платьем. Женщины уделяют гораздо больше внимания качеству пошива, богатству и выразительности отделки. Отдавая предпочтение традиционному варианту и отказываясь от так называемого европейского белого платья, они тем самым подчёркивают важность события, характеризующегося сменой социального статуса, а также маркируют свою этническую принадлежность. Данная модель платья символизирует единство духовной жизни албанского этноса и отдельного его представителя. Благодаря включению в комплекс таких элементов, как брез и шкокат, свадебный костюм приобретает особый сакральный смысл в сознании носителей.

Современное производство традиционной одежды по-прежнему является ручным трудом несмотря на то, что уже нет специалистов, способных сплести на коклюшках кружево из золотной нити, поскольку из-за ненадлежащего качества представленного на современном рынке золота, во время обработки нить постоянно рвется (ПМА 3). Однако есть несколько частных мастерских, где занимаются изготовлением костюмов на заказ, поэтому арбрешские женщины по-прежнему покупают традиционную одежду для особых случаев. Одной из новых тенденций стал пошив одежды для детей. Девочек наряжают в уменьшенные копии женских костюмов, но без использования украшений и аксессуаров, а мальчиков в традиционную албанскую одежду, купленную на Балканах (ПМА 4).

В наши дни в большинстве семей Пьана-дельи-Альбанези имеется хотя бы один костюм, украшенный вышитым орнаментом золотого и серебряного цвета. Приведем цитату из нарратива Стефано Скиро (арбреш, 1988 г. р., Пьяна-дельи-Альбанези):

«В основном женские костюмы передаются от матери к дочери по наследству, поскольку изготовление на заказ стоит дорого, и не все могут это позволить. Стоимость полного комплекта праздничного костюма в 2008 году составляла приблизительно пятнадцать тысяч евро, в то время как свадебного - больше двадиати. К 2020 году стоимость костюма для Пасхи увеличилась до тридиати тысяч евро. В последнее время всё более популярной становится практика одалживания традиционной одежды у знакомых» (ПМА 3: Скиро).

Популяризация ношения традиционного костюма приобретает всё более выраженный характер. Существуют различные ассоциации, занимающиеся продвижением народной культуры арбрешей в современных СМИ. По словам информантки Джузеппины Скиро (арбрешка, 1970 г. р., Пьяна-дельи-Альбанези) организация 
«Pro-Loco» ${ }^{1}$ каждый год на Пасху устраивает розыгрыш лотереи, причём билеты вручаются тем, кто носит традиционную одежду как в пасхальное воскресенье, так и в течение Страстной недели. Кроме того, деятельность «Pro-Loco» направлена на распространение информации, связанной с историей и правилами ношения женских костюмов, поскольку за последние тридцать лет была зафиксирована тенденция неверной интерпретации традиционной одежды и ее отдельных элементов современной молодежью (ПМА 3: Дж. Скиро).

Также известны случаи использования женского костюма в рекламе и полиграфии. Так, в 1950 году была выпущена серия почтовых открыток, включавшая шесть хромолитографий с изображением традиционной одежды Сицилии, две из которых были посвящены нарядам Пьяна-дельи-Альбанези (в то время Пьяна-деи-Гречи). В последние годы женские костюмы были неоднократно задействованы в продвижении фестиваля канноли ${ }^{2}$, а также рекламы сицилийской кухни, причём не все зрители отреагировали положительно. По мнению информантов, такая реклама выглядит весьма сомнительно и не вызывает одобрения в выборе лица, представляющего рекламный образ кампании.

Возмущение местных жителей вызывает и то, что традиционная одежда Пьяна-дельи-Альбанези представлена в качестве символа общесицилийской культуры, при этом нарушается право авторства, принадлежащее арбрешам как представителям отдельного этнокультурного сообщества. В качестве иллюстрации приведем слова информантов:

«К сожалению, интересы нашей общины не защищаются на законодательном уровне. До тех пор, пока правительство не начнет действовать, нашу традиционную одежду будут продолжать использовать в рекламе гостинич и ресторанов. Такое кощунственное отношение к нашим культурным ценностям лишает нас дара речи. Поступать так - все равно что вскрывать чью-то могилу» (ПМА 4: Паррино).

«B нашей традищии костюм очень ценная одежда не только с экономической, но и культурной точки зрения, поэтому он должен использоваться в исключительных случаях, необходимо сохранять должное уважение и канонические условия его ношения. Для нас очевидно, что даже в рекламных целях прибегать к пошлости неприемлемо. Священное и мирское, безусловно, следует сравнивать, но в разумных пределах.» (ПМА 3: Дж. Скиро).

Данные высказывания свидетельствуют о том, что традиционная женская одежда является для носителей сакральным компонентом собственной культуры. Одним из ключевых факторов, повлиявших на формирование такого представления, стал религиозный, проявившийся в костюме арбрешей в наборе специальных символов. Именно он на протяжении длительного времени модифицировал заимствованные элементы, выстраивая тот облик костюма, который албанский этнос воспринимал как свой.

Арбреши считают себя хранителями и продолжателями собственных этнокультурных традиций, поэтому стараются создать и законсервировать некий тип костю-

\footnotetext{
${ }^{1}$ Pro-Loco - организация, занимающаяся продвижением традиционной культуры арбрешей Пьянадельи-Альбанези в средствах массовой информации (https:/www.prolocopianadeglialbanesi.com).

${ }^{2}$ Канноли (итал. cannoli «трубочки») - традиционный сицилийский десерт, представляющий собой вафельную трубочку с начинкой из сыра рикотты.
} 
ма, который несмотря на включённость заимствованных элементов, воспринимается носителями и транслируется в мировое сообщество как национальный.

\section{Основные выводы}

Создание этнического костюма - это сложный процесс, представляющий собой определённое перекодирование жизненного опыта, полученного в результате многовекового взаимодействия с другими народами, в зрительные образы. Одежда тесно связана с материальной и духовной культурой людей, языковыми контактами, а также с ритуальными и социальными составляющими жизни любого этноса.

Традиционная одежда арбрешей Италии и Сицилии - это целостное этнокультурное явление, веками создаваемое и продолжающее жить в современном социокультурном пространстве. Женские костюмы Пьяна-дельи-Альбанези представляют собой синтез традиций и искусства и выполняют важную этнодифференцирующую функцию. Тот вариант костюма, который сегодня арбреши позиционируют как свой национальный, является результатом объединения отличительных признаков собственной культуры и приобретенных с течением веков новых характеристик под влиянием религиозного фактора.

Для традиционной одежды арбрешей характерны следующие черты: относительная устойчивость основных моделей женского платья, вариативность отдельных элементов внутри комплексов, заимствование предметов одежды в результате длительного межкультурного взаимодействия с представителями доминантной культуры, а также сильное влияние европейской моды на окончательное формирование внешнего облика костюма. В совокупности эти черты представляют этническую специфику арбрешской традиционной одежды, затрудняющую или даже исключающую в настоящее время какие-либо серьезные инновации. Сакральное отношение к такому элементу культуры, как костюм, по-прежнему является главным условием сохранения и популяризации этнического наследия арбрешей.

Несмотря на серьезное влияние социоэкономической модернизации и различные межэтнические взаимодействия, приведшие к значительным трансформациям в традиционной культуре и традиционных установках представителей албанского этноса, женские костюмы продолжают сохраняться в культурной памяти арбрешей и являются одним из основных механизмов репрезентации и передачи культурного кода, а также позиционирования этнической принадлежности в условиях проживания в полиэтничном обществе.

\section{Источники}

Siragusa 2009 - Siragusa C. Il matrimonio arbëresh a Piana degli Albanesi. Tradizione e innovazione. Università degli studi di Palermo. Facoltà di lettere e filosofia. Matricola № 0434460. Palermo. 2009.

ПМА 1 - Полевые материалы автора. Экспедиции в с. Зичишт, краина Корча (Албания). 2014 2015 гг. Свадебная обрядность албанцев и традиционный свадебный костюм. Полевая тетрадь. ПМА 2 - Полевые материалы автора. Экспедиции в г. Приштина, Косово. 2015 г. Традиционный костюм албанцев Косово. Полевая тетрадь.

ПМА 3 - Полевые материалы автора. Экспедиция в с. Пьяна-дельи-Альбанези, провинция Палермо, (Сицилия). 2016-2017 гг. Полевая тетрадь: информанты - С. Скиро 1988 г.р., Г. Паррино 1990 г.р., Дж. Скиро 1970 г. р. и др. 
ПМА 4 - Полевые материалы автора. Удаленный опрос информантов из с. Пьяна-дельи-Альбанези, провинция Палермо, (Сицилия). 2019-2020 гг. (информант - Г. Паррино 1990 г.р.).

\section{Научная литература}

Андреева Р.П. Энциклопедия моды. СПб.: Литера, 1997. 416 с.

Арш Г.Л. Иванова Ю.В., Колпакова О.А., Смирнова Н.Д. Краткая история Албании: С древнейших времен до наших дней / под ред. Г. Л. Арша. М.: Наука, 1992. 512 с.

Новик А.А. Украшения арбрешей Италии // Материалы полевых исследований МАЭ РАН. / отв. ред. Е.Г. Федорова. Вып. 2011 г. СПб.: МАЭ РАН, 2011. С. 133-154.

Плужников В.И. Термины российского архитектурного наследия: Словарь-глоссарий. М.: Искусство, 1995. $160 \mathrm{c.}$

Сулоева М.А., Скиро С. Арбреши Сицилии: сохранение свадебного костюма (полевые материалы 2016-2017 гг.) // ХІІ Конгресс антропологов и этнологов России: сборник материалов. Ижевск, 3-6 июля 2017 г. / отв. ред.: А.Е. Загребин, М.Ю. Мартынова. Москва; Ижевск: ИЭА РАН, УИИЯЛ УрО РАН, 2017. С. 89-90.

Сулоева М.А., Скиро С. Традиционный женский костюм арбрешей Италии в контексте современной культуры // XIII Конгресс антропологов и этнологов России: сборник материалов. Казань, 2-6 июля 2019 г. / отв. ред. М. Ю. Мартынова. Москва; Казань: ИЭА РАН, КФУ, Институт истории им. Ш. Марджани АН РТ, 2019. С. 458-459.

Bellusci C., D'Agostino F. Dizionario illustrato italiano-arbërisht-shqip. Storia e lingua albanese di Acquaformosa, Civita, Ejanina, Firmo, Frascineto, Lungro, San Basile e dell'Albania. Vol. I. Collana: Minoranze Linguistiche. Montalto Uffugo: Edizioni Orizzonti Meridionali, 2006.

Di Natale M.C. Gioielli di Sicilia. Palermo: Flaccovio, 2000, 223 p.

Emmanuele D. Arberia: storia, cultura e folklore. Castrovillari, 1988, 260 p.

Gjergji A. Veshjet shqiptare në shekuj. Origjina. Tipologjia. Zhvillimi. Tiranë: Akademia e Shkencave e RPS të Shqipërisë: Instituti i Kulturës Popullore, 1988. 285 f.

Guagliardi D. La comunità albanese di Sicilia // La Diversità Arbëreshe. Vol. I: La formazione, la storia, l'insediamento. Cosenza: Falco Editore, 2004. 368 p.

La Barbera M. Il costume e i gioielli di Piana degli Albanesi // Tracce d'Oriente, catalogo della Mostra / A cura di M.C. Di Natale). Palermo 2007, Pp. 111-131.

Manali P. Hora e Arbëreshëvet. Piana degli Albanesi. Palermo: Comune di Piana degli Albanesi, 2005.

Mastroberti F. Le colonie albanesi nel Regno di Napoli tra storia e storiografia. Bari: Università degli studi di Bari. Cacucci editore 2008, Pp. 241-251.

Romata E. I paesi italo-albanesi dell'italia meridionale. l'Accademia Nazionale delle Scienze di Washington, 1964. $27 \mathrm{p}$.

Russo L. Albanesi d'Italia. Palma Palermo, 1975.

Schirò G.D. Il costume tradizionale femminile di Piana degli Albanesi: fronti iconografiche // Miscellanea arbëreshe / A cura di Pietro Manali. Quaderni di Biblos: Società e Instituzioni 30/6. Palermo: Unione dei Comuni Besa, 2011. Pp. 231-250.

Schirò G. D. Tradizione ed evoluzione nel costume femminile arbëresh. In: Biblos, 2009. Pp. 91-104.

Schirò S. Per una storia del brezi: la cintura tradizionale di Piana degli Albanesi negli scritti di Sidney J.A. Churchill // Rivista dell'Osservatorio per le arti decorative in Italia. Palermo 2015. DOI: $10.7431 /$ RIV10082014.

Sciascia S. Arte popolare e artigianato in Sicilia: Repertorio dell'artigianato siciliano // Unione delle Commercio Industria ed Agricultura della Regione Siciliana. Rome: Salvatore Sciascia Editore, $1966.140 \mathrm{p}$.

Thomai et al. Fjalor i shqipes së sotme. Tiranë: TOENA, 2002.

Zangari D. Le Colonie Italo-Albanesi di Calabria. Napoli, 1940. 175 p. 
Suloeva, Marina A.*

\section{Role and functioning of traditional female Arbresh clothes in Italy in modern sociocultural space}

DOI: $10.33876 / 2311-0546 / 2020-52-4 / 45-63$

The article is devoted to the traditional women's clothing of the Arbresh diaspora in Piana degli Albanesi in Sicilia. The Arbresh are immigrants from the Balkan Peninsula who migrated to Italian lands in the 15th century. The traditional clothes of Piana degli Albanesei are considered as an integral ethnocultural phenomenon that has been being created for centuries and continues to exist in the modern sociocultural space. The author traces the change in women's costume and reveals the specifics of its individual elements functioning. The Arbresh consider themselves to be keepers and successors of their own traditions, so they try to create and preserve a certain type of costume, which, despite the borrowed elements, is perceived and transmitted to the world community as an ethnic one. The research base of the work was made up of ethnographic and art studies, as well as the author's own field materials collected during fieldwork in Sicily in Piana degli Albanesi and Palermo (2016-2017), in Kosovo (2015) and southern Albania (2014-2015).

Key words: Arbresh diaspora, Piana degli Albanesi, female traditional clothes, identity, traditions, cultural memory

* Suloeva, Marina A. - PhD student, Peter the Great Museum of Anthropology and Ethnography (SeintPetersburg, Russia). E-mail: suloevamarina@yandex.ru

\section{References}

Andreeva, R.P. 1997. Entsiklopediia mody [Fashion Encyclopedia]. St. Petersburg: Litera.

Arsh, G.L., Iu.V. Ivanova, O.A. Kolpakova, and N.D. Smirnova. 1992. Kratkaia istoriia Albanii: $S$ drevneishikh vremen do nashikh dnei [A Brief History of Albania: From Ancient Times to the Present], edited by G. L. Arsh, G. L.Moscow: Nauka.

Novik, A.A. 2011. Ukrasheniia arbreshei Italii. Materialy polevykh issledovanii MAE RAN. [Jewelry of the Arbëreshë people in Italy]. In Materials of Field Research MAE RAS, edited by E.G. Fedorova. St. Petersburg: MAE RAN: Pp. 133-154.

Pluzhnikov, V.I. 1995. Terminy rossiiskogo arkhitekturnogo naslediia: Slovar'-glossarii. [Terms of Russian Architectural Heritage: Glossary]. Moscow: Iskusstvo.

Suloeva, M.A., and S. Skiro. 2019. Arbreshi Sitsilii: sokhranenie svadebnogo kostiuma (polevye materialy 2016-2017 gg.). [The Arbëreshë people of Sicily: preserving a wedding suit (field materials 2016-2017)]. XII Kongress antropologov i etnologov Rossii: sbornik materialov. Izhevsk, 3-6 iiulia 2017 g. [XII Congress of Anthropologists and Ethnologists of Russia: a collection of materials. Izhevsk, July 3-6, 2017], edited by A.E. Zagrebin, M.Yu. Martynova, 89-90. Moscow; Izhevsk: IEA RAN, UIIIaL UrO RAN.

Suloeva, M.A., and S. Skiro. 2019. Traditsionnyi zhenskii kostium arbreshei Italii v kontekste sovremennoi kul'tury. [The traditional female costume of the Arbëreshë people in Italy in the context of modern culture]. XIII Kongress antropologov i etnologov Rossii: sbornik materialov. Kazan', 2-6 iiulia 2019 g. [XIII Congress of Anthropologists and Ethnologists of Russia: a collection of materials. Kazan, July 2-6, 2019] ], edited by A.E. Zagrebin, M.Yu. Martynova, 458-459. Moscow; Izhevsk: IEA RAN, UIIIaL UrO RAN.

Bellusci C., and F. D'Agostino. 2006. Dizionario illustrato italiano-arbërisht-shqip. Storia e lingua albanese di Acquaformosa, Civita, Ejanina, Firmo, Frascineto, Lungro, San Basile e dell'Albania. [Illustrated dictionary english-arbërisht-shqip. History and Albanian language of Acqua- 
formosa, Civita, Ejanina, Firmo, Frascineto, Lungro, San Basile and of Albania]. Vol. I. Collana: Minoranze Linguistiche. Montalto Uffugo: Edizioni Orizzonti Meridionali.

Di Natale M.C. 2000. Gioielli di Sicilia. [Jewels of Sicily]. Palermo: Flaccovio.

Emmanuele D. 1988. Arberia: storia, cultura e folklore. [Arberia: history, culture and folklore]. Castrovillari.

Gjergji A., 1988. Veshjet shqiptare në shekuj. Origjina. Tipologjia. Zhvillimi. [Albanian clothes for centuries. Origin. The typology. Development.]. Tiranë: Akademia e Shkencave e RPS të Shqipërisë: Instituti i Kulturës Popullore.

Guagliardi D., 2004. La comunità albanese di Sicilia. [The Albanian community of Sicily]. La Diversità Arbëreshe: La formazione, la storia, l'insediamento [Arbëreshe Diversity: Formation, history, settlement]. Vol. I. Cosenza: Falco Editore.

La Barbera M., 2007. Il costume e i gioielli di Piana degli Albanesi. [The costume and jewels of Piana degli Albanesi]. Tracce d'Oriente, catalogo della Mostra [Traces of the East, catalog of the exhibition], edited by M.C. Di Natale. Palermo.

Manali P., 2005. Hora e Arbëreshëvet. Piana degli Albanesi. [Hora e Arbëreshëvet. Piana degli Albanesi]. Palermo: Comune di Piana degli Albanesi.

Mastroberti F., 2008. Le colonie albanesi nel Regno di Napoli tra storia e storiografia. [The Albanian colonies in the Kingdom of Naples between history and historiography], 241-251. Bari: Università degli studi di Bari; Cacucci editore.

Romata E. 1964. I paesi italo-albanesi dell'italia meridionale. [The Italian-Albanian countries of southern Italy]. l'Accademia Nazionale delle Scienze di Washington.

Russo L. 1975. Albanesi d'Italia. [Albanians of Italy]. Palma Palermo.

Schirò G.D. 2001. Il costume tradizionale femminile di Piana degli Albanesi: fronti iconografiche. [The traditional female costume of Piana degli Albanesi: iconographic fronts]. In Miscellanea arbëreshe, edited by Pietro Manali, 231-250. Quaderni di Biblos: Società e Instituzioni 30/6. Palermo: Unione dei Comuni Besa.

Schirò G.D. 2009. Tradizione ed evoluzione nel costume femminile arbëresh. [Tradition and evolution in women's costume arbëresh]. In: Biblos: 91-104.

Schirò S. 2014. Per una storia del brezi: la cintura tradizionale di Piana degli Albanesi negli scritti di Sidney J.A. Churchill. [For a history of brezi: the traditional belt of Piana degli Albanesi in the writings of Sidney J. A. Churchill]. Rivista dell'Osservatorio per le arti decorative in Italia. Palermo. DOI: 10.7431/RIV10082014.

Sciascia S. 1966. Arte popolare e artigianato in Sicilia: Repertorio dell'artigianato siciliano. [Popular art and crafts in Sicily: repertoire of Sicilian crafts]. Unione delle Commercio Industria ed Agricultura della Regione Siciliana. Rome: Salvatore Sciascia Editore.

Thomai J. 2002. Fjalor $i$ shqipes së sotme. [The dictionary of modern Albanian language]. Tiranë: TOENA.

Zangari D. 1940. Le Colonie Italo-Albanesi di Calabria. [The Italian-Albanian colonies of Calabria Napoli]. Naples. 